\title{
Determination of Essential Amino-acids in some Ceylon Vegetables
}

\author{
BY N. G. BAPTIST \\ Biochemical Laboratory, Department of Physiology, University of Ceylon, Colombo
}

(Received I8 August 1953)

Until recently methods of amino-acid analysis had been applicable only to purified proteins. In a few instances the effects of impurities have been partly ascertained, noteworthy being the work of Chibnall and his colleagues (Chibnall, 1939) and of Lugg (I938a) on the crude proteins of grasses. The development of the microbiological method in recent years has led to an extension of analysis to relatively crude proteins and even to whole foods. In 1946, I began at the Biochemical Laboratory, Cambridge, and at the Human Nutrition Unit, Medical Research Council, London, a study of the applicability of some recent developments in amino-acid analysis (Macpherson, 1946; Rees, 1946; Tristram, 1946; Stokes, Gunness, Dwyer \& Caswell, r945) to dried foodstuffs from which the fat and water-soluble components had been removed. Latterly I have resorted largely to the microbiological method, owing to its greater applicability to the hydrolysates of crude proteins.

The main difficulty of doing amino-acid estimations on crude proteins is in evaluating the destruction of amino-acids brought about by strong acid at high temperatures in the presence of contaminating carbohydrate. I have attempted this evaluation by comparing the essential amino-acid values obtained after (I) direct hydrolysis of the crude proteins in the presence of the associated water-insoluble carbohydrate; and (2) hydrolysis of the acid-soluble material extracted from the crude protein. By also determining several amino-acids in some of the unextracted foodstuff preparations, an attempt has been made to ascertain how far the crude proteins as prepared are representative of the total protein of the foodstuffs. The vegetables used in this study have a complex chemical composition, and it was considered that methods applicable to them could probably be extended to other foodstuffs. This paper reports the results so obtained and evaluates their usefulness for estimating the essential amino-acids in crude proteins.

\section{EXPERIMENTAL}

\section{Preparation of material for analysis}

Preparation of dry defatted residue. The group of foodstuffs selected for study was representative of vegetables commonly consumed in Ceylon. The fresh vegetable was cut up if necessary and the portions usually discarded during preparation for the table were rejected. The remainder was immediately dried in a rapid drier at $60-70^{\circ}$. The dry material was further dried at $105^{\circ}$, ground to a fine powder in an end-runner mill or a laboratory disintegrator and then sifted through a 90-mesh Monel sieve. The dry sifted powder was exhaustively extracted with $96 \%$ alcohol, light petroleum 
(b.p. $60-80^{\circ}$ ) and hot water. The wet material was then dehydrated with acetone and dried at 100-105. . It will be referred to as 'crude protein'.

Losses in weight were recorded after each extraction. Determinations of nitrogen were carried out on the unextracted dry preparation, on the alcohol-petroleum extracted material and on the alcohol-petroleum-water extracted material. Moisture was determined simultaneously. All nitrogen determinations in these investigations were carried out by the micro-Kjeldahl procedure of Chibnall, Rees \& Williams (1943).

Acid hydrolysis. Direct hydrolysis with $20 \% \mathrm{HCl}$ leads to the formation of furfural from pentosan impurities. Furfural reacts with amino-acids and is likely to lead to considerable destruction. A trial experiment, in which the extraction of nitrogen by dilute hydrochloric acid (Miller, I935; Tristram, 1939) was followed, showed that the bulk of the nitrogen could be extracted with boiling $0.5 \mathrm{~N}$-hydrochloric acid and that the extraction was relatively complete after some time. The following procedure was therefore adopted.

A portion of material containing about $50 \mathrm{mg}$ nitrogen (simultaneous determination of moisture was made) was refluxed gently over a micro-burner with $100 \mathrm{ml} .0 .5 \mathrm{~N}-$ $\mathrm{HCl}$ for $16-24 \mathrm{~h}$. The residue was separated and washed three times with water by centrifugation. If a slight turbidity was present in the solution, it was filtered through a Whatman no. 42 filter-paper. The residue was dried at $100-105^{\circ}$ and total nitrogen was determined. The solution was evaporated three times to dryness under reduced pressure after the addition of water to remove the last traces of acid, and the residue was taken up in $50 \mathrm{ml} .20 \% \mathrm{HCl}^{*}$. This solution was boiled gently for $15^{-20} \mathrm{~h}$ and $\mathrm{HCl}$ was removed by evaporation under reduced pressure, the last traces of acid being removed as before. The humin was separated by centrifuging and washed with water, and its total nitrogen was determined. The clear liquid was made up to volume and its total nitrogen determined. Typical results with two preparations were as follows:

\begin{tabular}{lcccc} 
& \multicolumn{2}{c}{ (Values quoted are percentages of total nitrogen) } & Final N \\
& Residual N & Humin N & Final N & by difference \\
Murunga leaf & $\mathbf{1 7 \cdot 8}$ & $5 \cdot 5$ & $77 \cdot 2$ & $76 \cdot 7$ \\
Brinjal & $16 \cdot 7$ & $6 \cdot 4$ & $77 \cdot 6$ & $76 \cdot 9$
\end{tabular}

The close agreement of the figures for residual $\mathrm{N}$ is fortuitous. In practice any figure between 5 and $30 \%$ of the total nitrogen may be obtained according to the time employed for the preliminary extraction and the nature of the material. The above figures are considered representative for an overnight boiling. In the trial experiment referred to earlier, for instance, a total of $95 \%$ of the total nitrogen was extracted in $4^{2} \mathrm{~h}$. Too long a preliminary extraction, however, tended to produce some humin formation at this stage and the shorter periods were used. Suitable portions of these 'extraction' hydrolysates were taken for estimation of the leucines, valine, phenylalanine and methionine by chromatography on silica gel; of arginine, histidine and lysine by electrodialysis; of threonine by periodate oxidation; and of leucine, isoleucine, valine, phenylalanine, methionine, threonine and lysine by microbiological assay.

* Unless otherwise stated, all $\mathrm{HCl}$ used was of analytical reagent grade. 
Direct hydrolysis. The direct hydrolysates were prepared by boiling with $100 \mathrm{ml}$. $20 \% \mathrm{HCl}$ for $20 \mathrm{~h}$ after a preliminary heating on the water-bath to dissolve the material. The subsequent procedure was identical with that used for the 'extraction' hydrolysates. For the determination of leucine by microbiological assay hydrolysis was also carried out by heating in the autoclave for $6-7 \mathrm{~h}$ with $25 \mathrm{ml} .2 \mathrm{~N}-\mathrm{HCl} / \mathrm{g}$ material (Schweigert, McIntire, Elvehjem \& Strong, 1944). The acid hydrolysate was neutralized with $\mathrm{NaOH}$ to $\mathrm{pH}_{4}$ and extracted with ether and toluene before being made up to volume.

Alkaline hydrolysis. For the determination of tryptophan by microbiological assay, hydrolysis was carried out by the procedure of Greene \& Black (1944). For the determination of tryptophan by the Folin-Lugg procedure, the alkaline hydrolysates were prepared as outlined by Lugg (1938c).

\section{Methods studied}

Arginine and histidine Lysine

Threonine

Cystine

Methionine

Tryptophan

Leucine

Isoleucine

Valine

Phenylalanine

\section{Analytical methods}

Electrodialysis (Macpherson, I946)

Electrodialysis (Macpherson, I946); microbiological assay with (I) Streptococcus faecalis (Stokes et al. 1945), (2) Leuconostoc mesenteroides P 60 (Henderson \& Snell, 1948)

Periodate oxidation (Rees, I946); microbiological assay with Strep. faecalis (Henderson \& Snell, 1948; Greenhut, Sirny \& Elvehjem, I948)

Sulphur distribution by differential oxidation (Lugg, $1938 b$ )

Sulphur distribution by differential oxidation (Lugg, 1938b); microbiological assay with Strep. faecalis (Henderson \& Snell, 1948); chromatography on silica gel (Tristram, 1946)

Folin reaction (Lugg, 1938a); microbiological assay with Lactobacillus arabinosus 17-5 (Wooley \& Sebrell, 1945)

Chromatography on silica gel (Tristram, I946); microbiological assay with (I) Lb. arabinosus 17-5 (Schweigert et al. 1944); (2) Strep. faecalis (Henderson \& Snell, 1948)

Chromatography on silica gel (Tristram, 1946); microbiological assay with Strep. faecalis (Henderson \& Snell, 1948)

Chromatography on silica gel (Tristram, I946); microbiological assay with Strep. faecalis (Henderson \& Snell, r948)

Chromatography on silica gel (Tristram, 1946); microbiological assay with Leuc. mesenteroides P6o (Henderson \& Snell, 1948)

\section{Microbiological assay}

General. Unlike some of the chemical methods, this assay can be applied directly to hydrolysates of crude proteins. Ever since the beginning of this work, numerous modifications of existing methods for the assay of amino-acids by means of different organisms and in different media have been reported in the literature. Perhaps the most satisfactory medium is that of Henderson \& Snell (1948), as it is suitable for several different organisms and (with $240 \mu \mathrm{g}$ pyridoxin in place of $40 \mu \mathrm{g}$ pyridoxal/100 $\mathrm{ml}$. double-strength medium in many of the earlier assays, owing to nonavailability of pyridoxal) has been used by me for the determination of lysine and phenylalanine with Leuc. mesenteroides $\mathrm{P} 60$ and of valine, threonine, isoleucine and methionine with Strep. faecalis. In addition, many determinations of leucine were also 
carried out with Strep. faecalis, of phenylalanine with $L b$. arabinosus $17-5$, and of isoleucine and methionine with Leuc. mesenteroides $\mathrm{P} 60$ in the same medium, giving results in good agreement. All the assays were carried out in duplicate on each of at least two hydrolysates. In general, the hydrolysates were assayed at three to five dose levels in the recommended assay range. Control assays in which known portions of standard solutions were added to the assay solution were carried out every time; if the recovery of added amino-acid was below $95 \%$ or above $105 \%$, the assay value was disregarded and the assay repeated.

Cultures and inocula. The cultures were obtained from the National Collection of Industrial Bacteria, Department of Scientific and Industrial Research, Teddington, England, and were maintained in the medium used by Henderson \& Snell (1948). Inocula were prepared by transfer from the stock culture to $\mathrm{Io} \mathrm{ml}$. liquid medium of the same composition, but with the agar omitted, and grown for $12-24 \mathrm{~h}$ at $37^{\circ}$. The cells were centrifuged and washed twice by centrifugation after resuspension each time in a volume of $10 \mathrm{ml}$. sterile $0.9 \%$ sodium-chloride solution. The cells were finally suspended in $10 \mathrm{ml}$. sterile saline and one drop of the suspension was used to inoculate each assay bottle.

Procedure. Assays were carried out in I oz. cylindrical glass bottles with perforated metal screw caps and rubber washers and in a total volume of $10 \mathrm{ml}$. This volume was later reduced to $6 \mathrm{ml}$. without affecting the precision of the assays. The samples or standards were in volumes of from 0.2 to $3.0 \mathrm{ml}$; ; water was first added to make up to a total of $3.0 \mathrm{ml}$., and then $3.0 \mathrm{ml}$. of the basal medium, prepared at double strength. All additions were made with calibrated pipettes. The bottles were then loosely capped and sterilized by autoclaving at Io $\mathrm{lb}$. pressure for to $\mathrm{min}$. After sterilizing, the bottles were placed in a small glass chamber previously freed of dust with steam, and after cooling were inoculated through the rubber washer with one drop of inoculum from a sterile syringe. It was found later that the inoculation could be safely performed by lifting the metal cap, adding a drop of inoculum, quickly replacing the cap and screwing it down tight. After incubation for $65-72 \mathrm{~h}$ at $37^{\circ}$, I ml. bromothymolblue indicator solution (Lubs \& Clark, 1915) was added to each bottle and the lactic acid produced was titrated against $0.05 \mathrm{~N}-$ or $0.1 \mathrm{~N}-\mathrm{NaOH}$ in a volume made up to $30 \mathrm{ml}$. by addition of distilled water.

\section{RESULTS}

Table I gives the nitrogen contents of the unextracted dried preparations, the alcoholpetroleum extracted materials and the alcohol-petroleum-water extracted materials ('crude proteins'). Table 8 gives the losses of weight and of nitrogen at the various stages of extraction. Tables $3-7$ and Table 8 give the analytical values obtained in the comparative study. Table 2 gives the final analysis of the 'crude proteins' obtained by the procedures listed on p. 207.

For purposes of comparison, figures for ovalbumin (Block \& Bolling, 195I) are included in Table 2. Figures recorded in all the tables are the averages of duplicate or triplicate determinations, two or more hydrolysates being used for each. Thus each figure is the average of at least four determinations. In the differential oxidation 
procedure, in which the assay is made on the material without previous hydrolysis, the values are averages of triplicate determinations.

Table I. Nitrogen contents of unextracted and extracted vegetable preparations

(g N/100 g anhydrous material)

$\begin{array}{lccc}\text { Material } & \text { Raw } & \begin{array}{c}\text { Alcohol-petroleum } \\ \text { extracted }\end{array} & \begin{array}{c}\text { Alcohol-petroleum- } \\ \text { water extracted }\end{array} \\ \text { Murunga leaf (Moringa pterygosperma) } & 5 \cdot 01 & 5 \cdot 04 & 6 \cdot 23 \\ \text { Agati leaf (Sesbania grandiflora) } & 5 \cdot 71 & 6 \cdot 18 & 7 \cdot 48 \\ \text { Kankun leaf (Ipomoea aquatica) } & 4 \cdot 70 & 5 \cdot 02 & 6 \cdot 95 \\ \text { Okra (Hibiscus esculentus) } & 3 \cdot 26 & 3 \cdot 11 & 4 \cdot 47 \\ \text { Drumstick bean (Moringa pterygosperma) } & 3 \cdot 51 & 3 \cdot 67 & 4 \cdot 41 \\ \text { Jack seed (Artocarpus integrifloria) } & 1 \cdot 75 & 1 \cdot 79 & 2 \cdot 30 \\ \text { Brinjal (Solanum melongena) } & 2 \cdot 62 & 2 \cdot 83 & 4 \cdot 03\end{array}$

Table 2. Essential amino-acid composition of the 'crude proteins' of seven Ceylon vegetables.* Values for ovalbumin (Block $\mho^{\circ}$ Bolling, ${ }^{195} \mathrm{I}$ ) are quoted for comparison

(Amino-acid $\mathrm{N}$ as percentage of total $\mathrm{N}$ )

\begin{tabular}{|c|c|c|c|c|c|c|c|c|}
\hline Amino-acid & Ovalbumin & $\begin{array}{c}\text { Murunga } \\
\text { leaf }\end{array}$ & $\begin{array}{l}\text { Agati } \\
\text { leaf }\end{array}$ & $\begin{array}{c}\text { Kankun } \\
\text { leaf }\end{array}$ & Okra & $\underset{\text { bean }}{\text { Drumstick }}$ & $\begin{array}{l}\text { Jack } \\
\text { seed }\end{array}$ & Brinjal \\
\hline Arginine & $12 \cdot 2$ & $12 \cdot 0$ & $1 x \cdot 7$ & $9 \cdot 7$ & $5 \cdot 1$ & $7 \cdot 2$ & 3.9 & $6.8 \uparrow$ \\
\hline Histidine & $4^{\cdot I}$ & $3 \cdot 5$ & $3 \cdot 3$ & $2 \cdot 7$ & $1 \cdot 8$ & $I \cdot 8$ & $x \cdot 7$ & $2.9 \dagger$ \\
\hline Lysine & $7 \cdot 8$ & 5.2 & 4.8 & $4 \cdot 6$ & $3 \cdot 0$ & $x \cdot 8$ & $5 \cdot 8$ & $7 \cdot 0$ \\
\hline Tryptophan & $1 \cdot 3$ & $1 \cdot 6$ & $1 \cdot 4$ & $x \cdot 3$ & 0.6 & 0.7 & $I \cdot I$ & 0.8 \\
\hline Cystine & 1.8 & $2 \cdot 4$ & $I \cdot I$ & 1.5 & 0.6 & $2 \cdot 0$ & $I \cdot O$ & - \\
\hline Methionine & $3 \cdot 2$ & $x \cdot 2$ & 0.8 & $x \cdot 0$ & 0.7 & 0.8 & 0.8 & 0.5 \\
\hline Threonine & $3 \cdot I$ & $3 \cdot 6$ & $3 \cdot 5$ & $3 \cdot 6$ & $2 \cdot 8$ & $2 \cdot 9$ & $4 \cdot 3$ & $2 \cdot 7$ \\
\hline Phenylalanine & 4.0 & 3.4 & 3.2 & $3 \cdot 1$ & $2 \cdot I$ & $2 \cdot 3$ & $4 \cdot 1$ & $2 \cdot 3$ \\
\hline Leucine & $6 \cdot 3$ & $6 \cdot 2$ & 5.9 & $5 * 3$ & $4 \cdot I$ & $4: 3$ & $5 \cdot 3$ & 4.2 \\
\hline Isoleucine & 5.0 & $4 \cdot 2$ & $4 \cdot 1$ & $3 \cdot 8$ & $2 \cdot 8$ & $2 \cdot 9$ & $4 \cdot 8$ & $3 \cdot 4$ \\
\hline Valine & $4 \cdot 8$ & $5 \cdot 3$ & $5 \cdot 1$ & $4 \% 7$ & $4: 4$ & 4.0 & $6 \cdot 6$ & 4.4 \\
\hline
\end{tabular}

* Determined by the method set out on p. 207 .

$\uparrow$ Determined on the alcohol-petroleum extracted materials.

\section{Microbiological assay}

DISCUSSION

This method is subject to the limitation inherent in biological methods of assay, namely variability of response of the organism due to external stimulating or inhibiting factors. It has been used as a reference method in this study chiefly because of its direct applicability to all the essential amino-acids. Though the method is not immune to errors, there is no doubt that it has given valuable results in food-protein analysis, up to this time closed for those amino-acids, such as valine and isoleucine, for which no suitable chemical method of assay was available. On pure proteins it has given excellent agreement in recent years with analysis by the more precise chemical methods (Tristram, I95I). The presence of stimulating or inhibiting factors can be detected by recoveries of the added amino-acid under test; when such factors are shown to exist, an alternative organism or medium, or both, can be tried. When two or more organisms give linear responses, quantitative recoveries and close agreement in assay values at different levels, there is a high degree of probability that the method is yielding valid results. The errors, such as they are, for each amino-acid are mentioned in the following discussion. 
Some observations on the procedures applied to the analysis of individual amino-acids in 'crude proteins'

Lysine. For electrodialysis a Perspex cell with platinum electrodes, $2 \times \mathrm{I} \mathrm{cm}$, was used with a direct current of $230 \mathrm{~V}$; I IO V was found to be as satisfactory. The electrodialysis proceeded smoothly with the 'crude-protein' preparations, but as a rule the first run took a few hours longer to complete than with pure proteins. When the hydrolysate of the fat-extracted or the whole vegetable was used, the dialysis was unduly prolonged and never appeared to reach completion, as judged by the milliammeter reading. This method was therefore found applicable only to the crudeprotein' preparations. There was a tendency for the arginine estimation to be complicated by alkaline-earth ions from the 'crude protein' at the alkaline $\mathrm{pH}$ of the reaction; it was prevented or reduced to insignificant proportions by making the final catholyte to volume without preliminary acidification and filtering the solution before use.* In estimating lysine nitrogen by the difference between total-base nitrogen and the sum of the arginine and histidine nitrogen, a check was made at first on these 'difference' values for lysine by microbiological assay with Strep. faecalis. Table 3 shows values obtained for lysine by the two methods. Agreement for the leaf preparations and for jack seed is fairly good, but wide differences are apparent with the others.

\section{Table 3. Lysine content of the 'crude protein' of vegetables obtained by electrodialysis and microbiological assay}

(Amino-acid $\mathrm{N}$ as percentage of total $\mathrm{N}$ in 'extraction' hydrolysates)

\begin{tabular}{|c|c|c|c|}
\hline & \multicolumn{2}{|c|}{ By microbiological assay* } & \multirow{2}{*}{$\begin{array}{c}\text { By electrodialysis } \\
\text { Catholyte } \mathrm{N} \\
- \text { (arginine + histidine }) \mathrm{N}\end{array}$} \\
\hline & S.f. & L.m. & \\
\hline Murunga leaf & $4 \cdot 6$ & $5 \cdot 7$ & $5 \cdot 4$ \\
\hline Agati leaf & $4 \cdot 6$ & $4 \cdot 9$ & $5 \cdot 4$ \\
\hline Kankun leaf & $4 \cdot 6$ & $4 \cdot 6$ & $5 \cdot 4$ \\
\hline Okra & $2 \cdot 8$ & $3 \cdot 2$ & $6 \cdot 2$ \\
\hline Drumstick bean & $1 \cdot 7$ & $1 \cdot 9$ & 4.7 \\
\hline Jack seed & $5 \cdot 8$ & $5 \cdot 8$ & 5.9 \\
\hline Brinjal & $1 \cdot 8$ & $2 \cdot 0$ & $7 \cdot 8$ \\
\hline
\end{tabular}

It was found later that Leuc. mesenteroides $\mathrm{P} 60$ as the assay organism gave somewhat higher values (Table 3 , column 2) for some of the materials. That this was not due to experimental errors was shown by repeating assays on several different hydrolysates. Further, though Strep. faecalis on the medium of Stokes et al. (r945) gave a satisfactory standard curve with low blanks, this organism sometimes behaved erratically, especially in the lower ranges (below $4 \circ \mu \mathrm{g}$ ) with media containing the acetate-citrate buffer and higher concentrations of vitamins (Henderson \& Snell, I948; Greenhut et al. 1948). However, the response was sufficiently linear in the 40-100 $\mu \mathrm{g}$ range to make the method practicable for lysine. Though there is some evidence of a relationship between lysine requirement and pyridoxin for Strep. faecalis, there is no evidence of a similar relationship for Leuc. mesenteroides P60 (Lyman, Moseley, Wood, Butler \&

* The interference of alkaline earths in the estimation of arginine may also be suppressed by the addition of the chelating agent, ethylenediamine tetraacetic acid. 
Hale, 1947). This property has led to a preference for Leuc. mesenteroides $\mathrm{P} 60$ as the assay organism for lysine. This organism has the added advantage of higher acid production at low levels of added lysine. It is, however, apparent that the values obtained on 'crude-protein' preparations by the electrodialysis procedure are not always reliable. It seems likely that the catholyte fraction may contain basic nitrogenous compounds, such as glucosamine, which would contribute to their high nitrogen content. Edwards, Sealock, O'Donnell, Bartlett, Barclay, Tully, Tybout, Box \& Murlin (1946) have made a similar observation about the unreliability of the 'difference' value for lysine. They were, however, able to obtain good agreement between the microbiological method and the decarboxylase method under certain specified conditions applied to the original hydrolysate.

They also found good agreement between the values for arginine and histidine by electrodialysis and by microbiological assay. I have not considered it necessary therefore to check the values obtained by electrodialysis for these amino-acids.

Phenylalanine, leucine, isoleucine, valine. With pure proteins chromatography on silica gel is of particular value for estimation of the monoamino-acids. Two materials were used for preliminary study, namely the 'crude proteins' of murunga leaf and the alcohol-petroleum extracted brinjal. All the difficulties mentioned by Tristram (1946) were encountered and these were enhanced by the presence of the large humin fraction produced from the 'crude proteins', though not from the pure proteins. Agreement of duplicates was poor. In addition, the technical difficulties are relatively large and the method time-consuming. When the results were compared with those obtained by the microbiological method (Table 4), it was apparent that little reliance could be placed on the method. The low values obtained appear to be due to two chief causes, (I) a tendency for the fast-running humin fraction to carry variable amounts of acetylamino-acids with it and (2) the occurrence of true adsorption of acetylaminoacids on the silica, leading to losses during passage down the column. Consequently

\section{Table 4. Chromatography on silica gel compared with microbiological assay of five amino-acids in two 'crude protein' preparations} (Amino-acid $\mathrm{N}$ as percentage of total $\mathrm{N}$ in 'extraction' hydrolysates)

\begin{tabular}{|c|c|c|c|c|}
\hline \multirow{6}{*}{$\begin{array}{l}\text { Leucine } \\
\text { Isoleucine } \\
\text { Phenylalanine } \\
\text { Valine } \\
\text { Methionine }\end{array}$} & \multicolumn{2}{|c|}{ Murunga leaf } & \multicolumn{2}{|c|}{ Brinjal } \\
\hline & Chromatography* & $\begin{array}{c}\text { Microbiological } \\
\text { assay }\end{array}$ & Chromatography* & $\begin{array}{l}\text { Microbiological } \\
\text { assay }\end{array}$ \\
\hline & $8 \cdot 5$ & $\begin{array}{l}6 \cdot 2 \\
4 \cdot 0\end{array}$ & $3 \cdot I$ & $\begin{array}{l}4 \cdot 2 \\
3 \cdot 8\end{array}$ \\
\hline & $2 \cdot 8$ & $3 \cdot 2$ & $I \cdot 7$ & $2 \cdot 7$ \\
\hline & $3 \cdot 4$ & $5^{\cdot 1}$ & $2 \cdot 2$ & $4 \cdot 8$ \\
\hline & 0.0 & $I \cdot I$ & 0.0 & 0.5 \\
\hline
\end{tabular}

this method was discarded as impracticable for the analysis of impure proteins and the monoamino-acids were determined by the microbiological method alone. The microbiological assays of phenylalanine, leucine, isoleucine and valine appear to be reliable. Several different organisms yield values in good agreement (Hodson \& Krueger, 1947; N virl3 
Horn, Jones \& Blum, 1948, 1949). Also, good agreement has been obtained in the analysis of $\beta$-lactoglobulin between the starch-chromatogram method and microbiological assay for these amino-acids (Stein \& Moore, I948; Smith \& Greene, 1948). The values for the materials used by the two procedures are shown in Table 4 .

Tryptophan. Murunga leaf 'crude protein' was used in an exploratory study of the Folin-Lugg procedure. Complicating factors were the extraneous colour produced by the action of alkali on the carbohydrate residues of the 'crude protein' carried down with the mercury-tryptophan complex, and the instability of the pigment produced in the colour reaction with nitrite. The agreement in duplicate determinations, however, was reasonably good. As a check on this method the microbiological method was used and gave values in good agreement. This method has been shown to be valid by the detailed study of Horn \& Jones (I945), in which they compared the tryptophan contents of food proteins by the chemical and microbiological methods. The chief error in the microbiological method arises from incomplete racemization that may be produced by alkaline hydrolysis. Only L-tryptophan is active in microbial growth. For tryptophan nitrogen as percentage of total nitrogen in 'crude protein' of murunga leaf values of $I .66$ and $I \cdot 50$ were obtained by the colorimetric method and of $I \cdot 60$ and $\mathrm{I} \cdot 65$ by microbiological assay. In view of the reliability of the microbiological method, it was used exclusively for the other determinations.

Methionine. Lugg's (1938b) careful study with the crude proteins of plants $(12-15 \% \mathrm{~N})$ indicates a high degree of accuracy for methionine (and cystine) determinations by the 'differential oxidation' procedure, in the absence of other nonoxidizable sulphur compounds that might contribute to high methionine values (cf. comment of Lindan \& Work, 1951). Though this may be true for sufficiently purified plant proteins, it cannot be accepted as a general rule for proteins of less purity. In this study, the method was found to give good agreement between triplicate determinations, but the values for methionine were higher than those by the microbiological method (Table 5); a case in point is that of jack seed for which the values differ considerably. The microbiological method has been shown to give values in

\section{Table 5. Methionine content of the 'crude protein' of vegetables by differential oxidation and microbiological assay}

(Amino-acid $\mathrm{N}$ as percentage of total $\mathrm{N}$ )

\begin{tabular}{lcc} 
& $\begin{array}{c}\text { Differential } \\
\text { oxidation }\end{array}$ & $\begin{array}{c}\text { Microbiological } \\
\text { assay* }\end{array}$ \\
Murunga leaf & $1 \cdot 9$ & $1 \cdot 2$ \\
Agati leaf & $1 \cdot 0$ & $0 \cdot 8$ \\
Kankun leaf & $1 \cdot 2$ & $1 \cdot 0$ \\
Okra & $1 \cdot 0$ & $0 \cdot 7$ \\
Drumstick bean & $1 \cdot 2$ & $0 \cdot 8$ \\
Jack seed & $1 \cdot 4$ & $0 \cdot 8$ \\
\multicolumn{2}{c}{ *alue obtained after direct hydrolysis. }
\end{tabular}

good agreement with those obtained by colorimetric methods on acid hydrolysates of foodstuffs (Lyman, Moseley, Butler et al. I946; Horn et al. 1946a,b). It has been reported (Lyman \& Kuiken, 1948) that Strep. faecalis can utilize D-methionine 
in a citrate-buffered medium; as DL-methionine was used as standard in this assay, it is possible that the values obtained by using this organism are low. However, in later work on other food materials (Baptist, 1954) I have shown this organism to be reliable for methionine estimation, good agreement being found with values obtained with Leuc. mesenteroides $\mathbf{P} 60$.

Threonine. Values for threonine obtained by the chemical and microbiological procedures for this amino-acid show good general agreement, but the values by the microbiological method are usually a little higher (Table 6). The agreement between duplicates in either assay procedure was in general closer than in any other aminoacid estimation studied.

\section{Table 6. Threonine content of the 'crude protein' of vegetables by periodate oxidation and microbiological assay}

(Amino-acid $\mathrm{N}$ as percentage of total $\mathrm{N}$ in direct hydrolysates)

$\begin{array}{lcc}\text { Periodate } & \begin{array}{c}\text { Microbiological } \\ \text { oxidation }\end{array} & \begin{array}{c}\text { assay } \\ \text { Murunga leaf }\end{array} \\ \text { Agati leaf } & 3 \cdot 4 & 3 \cdot 8 \\ \text { Kankun leaf } & 3 \cdot 4 & 3 \cdot 5 \\ \text { Drumstick bean } & 3 \cdot 4 & 3 \cdot 8 \\ & 2 \cdot 9 & 2 \cdot 9\end{array}$

\section{Effect of hydrolytic procedure on destruction of amino-acids}

The impurities present in the protein preparations used would consist chiefly of water-insoluble carbohydrates, such as glucosans and pentosans. The destruction of the individual essential amino-acids during hydrolysis must therefore be considered. In the initial experiments, only the extraction procedure for preparing the hydrolysate was used in estimating the basic and monoamino-monocarboxylic acids. Destruction of amino-acids under these conditions would be minimal. The assumption was made that the fraction of nitrogen extracted was representative of the "crude-protein' preparation. In a detailed study this assumption has been shown to be valid for the lysine content of the 'crude protein' prepared from grasses by a somewhat different method (Tristram, I939). With the periodate method for estimating threonine it became possible to check the destruction of amino-acids caused by direct hydrolysis without preliminary extraction. It was apparent from the results that direct hydrolysis leads to destruction of threonine only slightly, if at all, greater than took place in the 'extraction' method of hydrolysis. These observations were extended to several other amino-acids estimated by the microbiological method, and the results obtained (Table 7) were similar to those obtained with threonine. Tristram (1939) has also shown that lysine is reasonably stable to acid hydrolysis in the presence of various carbohydrates (see also Edwards et al. 1946). The results obtained for lysine by the two hydrolytic procedures show good agreement and so support this conclusion. According to Rees (1946), about $5 \%$ of threonine is destroyed during acid hydrolysis of pure proteins; this destruction might well be enhanced in the presence of carbohydrate impurities. In the work reported here excellent duplication of results on both direct and 'extraction' hydrolysates was obtained for 'crude proteins' from widely 
different vegetables such as murunga leaf and okra. Many unpublished results from this laboratory also show good agreement of threonine values determined on pure proteins, such as coconut globulin and rice glutelin, with the values determined on the fat-extracted whole meals from which these proteins were prepared. It would seem, therefore, that the additional destruction of this amino-acid by large amounts of waterinsoluble impurities, mainly carbohydrate in nature, is negligible during hydrolysis with acid. It is possible that varying degrees of destruction of the other essential

Table 7. Comparison of values obtained for six amino-acids in the 'crude protein' by direct hydrolysis and 'extraction hydrolysis' of vegetables

(Amino-acid $\mathrm{N}$ as percentage of total $\mathrm{N}$ )

\begin{tabular}{|c|c|c|c|c|c|c|c|c|c|c|c|c|}
\hline \multirow{7}{*}{$\begin{array}{l}\text { Murunga leaf } \\
\text { Agati leaf } \\
\text { Okra } \\
\text { Jack seed } \\
\text { Brinjal }\end{array}$} & \multicolumn{4}{|c|}{ Chreonine* Methionine† } & \multicolumn{2}{|c|}{ Lysine } & \multicolumn{2}{|c|}{ Isoleucine $\uparrow$} & \multicolumn{2}{|c|}{ Valinet } & \multicolumn{2}{|c|}{$\begin{array}{l}\text { Phenyl- } \\
\text { alaninet }\end{array}$} \\
\hline & $\mathrm{D}$ & $\mathrm{E}$ & $\mathrm{D}$ & $\mathrm{E}$ & $\mathrm{D}$ & $\mathrm{E}$ & D & $\mathrm{E}$ & D & $\mathbf{E}$ & $\mathrm{D}$ & $\mathrm{E}$ \\
\hline & $3 \cdot 4$ & 3.4 & $I \cdot 2$ & $I \cdot I$ & $5 \cdot 7$ & $5 \cdot 7$ & $4 \cdot 2$ & 4.0 & $5 \cdot 3$ & $5 \cdot I$ & $3 \cdot 4$ & $3 \cdot 2$ \\
\hline & 3.4 & 3.4 & 0.8 & $I \cdot 0$ & 4.8 & 4.9 & $4 \cdot I$ & $4 \cdot 1$ & $5 \cdot 1$ & $4 \cdot 8$ & $3 \cdot 2$ & $2 \cdot 9$ \\
\hline & $2 \cdot 8$ & $2 \cdot 9$ & 0.7 & 0.8 & $2 \cdot 7$ & $3 \cdot 2$ & $2 \cdot 8$ & $3 \cdot 2$ & $4 \cdot 4$ & $4 \cdot 7$ & $2 \cdot I$ & $2 \cdot 3$ \\
\hline & $4 \cdot 3$ & $4 \cdot 4$ & 0.8 & 0.8 & $5 \cdot 8$ & 5.8 & $4 \cdot 8$ & 4.7 & $6 \cdot 6$ & 6.9 & $4 \cdot 1$ & 4.0 \\
\hline & $2 \cdot 9^{2}$ & $3 \cdot x^{2}$ & 0.5 & 0.5 & $I \cdot 8$ & $2 \cdot 0$ & 3.4 & $3 \cdot 8$ & $4 \cdot 4$ & $4 \cdot 8$ & $2 \cdot 3$ & $2 \cdot 7$ \\
\hline
\end{tabular}

monoamino-acids occur during acid hydrolysis of impure proteins. Methionine has been reported to be liable to decomposition and inactivation by heat in the presence of glucose (Graham, Hsu \& McGinnis, I949). It seems justifiable to assume that the carbohydrate impurities would lead to some loss of methionine in the hydrolytic procedure. The destruction of the other monoamino-acids, leucine, isoleucine, valine and phenylalanine does not appear to be serious under the conditions of hydrolysis employed. Alkaline hydrolysis is considered to cause some destruction of amino-acids, especially tryptophan (Synge, 1945). This evidently is not serious for tryptophan, since good agreement has been obtained more recently between the tryptophan contents in alkaline hydrolysates and enzymic hydrolysates of foodstuffs (Greene \& Black, I944; Wooley \& Sebrell, I945; Horn \& Jones, I945; Kuiken, Lyman \& Hale, 1947).

In trying to interpret these results nutritionally, the question arises whether these 'crude proteins' are representative of the whole proteins of the vegetables. Tristram (1939) prepared representative crude proteins from leaves by a slightly different procedure, in that he employed extraction with dilute acetic and citric acids. In a trial experiment with his method of extraction, it was found that the loss of nitrogen was as great as, and in fact somewhat greater than, with water. It was considered that the denaturation caused by treatment of the vegetable before extraction with water was sufficient to reduce the solubility of the proteins present. As can be seen from Table 8, there is a considerable loss of nitrogen in the two stages of extraction, which raises the question whether the protein in the extract corresponds in essential aminoacid content to the 'crude protein' left after the extraction procedure. To elucidate 
Table 8. Percentage weight losses and nitrogen losses (calculated on dry weight) after extraction of dry preparations of vegetables

\begin{tabular}{|c|c|c|c|c|}
\hline \multirow[b]{2}{*}{ Vegetable } & \multicolumn{2}{|c|}{$\begin{array}{l}\text { Extracted with } \\
\text { alcohol, petroleum }\end{array}$} & \multicolumn{2}{|c|}{$\begin{array}{c}\text { Extracted with } \\
\text { alcohol, petroleum, } \\
\text { water }\end{array}$} \\
\hline & Weight loss & $\mathrm{N}$ loss & Weight loss & $\mathbf{N}$ loss \\
\hline Murunga leaf & 25 & 25 & 52 & 40 \\
\hline Agati leaf & 25 & 19 & $6 I$ & 49 \\
\hline Kankun leaf & 48 & 45 & 76 & 64 \\
\hline Okra & 46 & $5 \mathbf{I}$ & 73 & 63 \\
\hline Drumstick bean & 30 & 27 & 62 & 52 \\
\hline Jack seed & 20 & 18 & $6 \mathrm{I}$ & 48 \\
\hline Brinjal & 27 & $2 \mathrm{I}$ & 58 & 36 \\
\hline
\end{tabular}

this point, assays were made of several amino-acids in the unextracted vegetable preparations. As can be seen from Table 9, the values obtained for tryptophan, leucine, methionine, threonine and phenylalanine show good agreement with the corresponding values for the 'crude proteins', indicating that such protein preparations are thoroughly representative of the original foodstuff. The results obtained permit

Table 9. Amino-acid contents of 'crude proteins' of vegetables compared with those of the unextracted dry preparations*

(Amino-acid $\mathrm{N}$ as percentage of total $\mathrm{N}$ in direct hydrolysates)

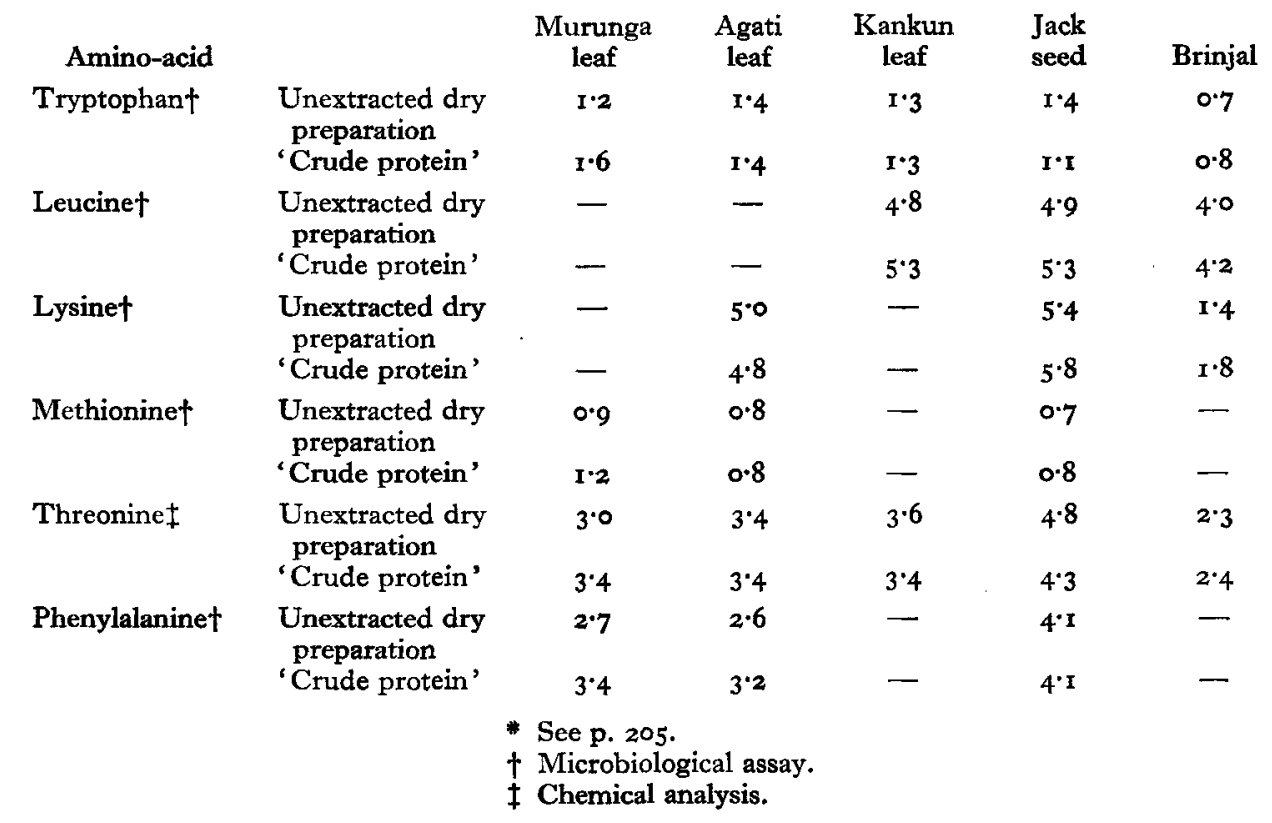

some conclusions as to the nutritive values of these vegetable proteins. The leaf proteins are in general superior to the others. In comparison with ovalbumin, they are deficient in methionine, but otherwise show no marked deficiencies. Jack-seed 
protein is deficient in arginine, histidine and methionine, but has comparatively high contents of the other essential amino-acids; those from other vegetables show several deficiencies, chiefly in the basic amino-acids and methionine, tryptophan and isoleucine.

\section{SUMMARY}

I. 'Crude-protein' preparations from seven Ceylon vegetables have been prepared by a process of desiccation and subsequent successive exhaustive extractions with alcohol, light petroleum and water.

2. The essential amino-acid contents of these 'crude proteins' have been determined by chemical and microbiological methods already recommended for the analysis of pure proteins.

3. The electrodialysis method for the basic amino-acids had a limited applicability to crude-protein preparations; the values obtained for lysine were frequently too high. Chromatography on silica gel could not be used satisfactorily for the determination of monoamino-acids in hydrolysates of 'crude proteins'. The periodate oxidation method for threonine has been shown to be applicable to 'crude-protein' hydrolysates and yielded values in good agreement with those by microbiological assay. The differential oxidation procedure for methionine gave results higher than those obtained by microbiological assay on acid hydrolysates. The microbiological-assay procedure for all the essential amino-acids has a wide applicability to 'crude proteins' and foodstuffs.

4. Destruction of essential amino-acids during hydrolysis appeared to reach a maximum with the comparatively small amount of non-protein material present in the acid-extractable fraction of 'crude proteins'. Results obtained with such hydrolysates agreed well with those obtained on direct hydrolysates of the 'crude proteins', containing large excesses of non-protein material.

5. The applicability of these methods to the analysis of such 'crude proteins' is discussed in the light of the results obtained.

6. Values obtained by microbiological assay for six amino-acids in the unextracted dry preparations themselves indicate that the 'crude-protein' preparations were representative of the total protein of the unextracted dry preparations.

7. The leaf-vegetable proteins proved somewhat deficient in methionine but otherwise showed no marked deficiencies of essential amino-acids and were in general superior to the other vegetable proteins studied.

The author wishes to thank the Secretary of State for the Colonies, U.K., for the grant of a Travelling Fellowship, 1946-7, during which this work was initiated; Professor A. C. Chibnall, F.R.S., Professor B. S. Platt, Dr G. R. Tristram, Dr H. T. Macpherson, Mr M. W. Rees for their advice and interest; and Messrs B. P. M. Perera and R. D. Sothary for technical assistance. 


\section{REFERENCES}

Baptist, N. G. (1954). Brit. F. Nutr. 8, 218.

Block, R. J. \& Bolling, D. (195I). The Amino Acid Composition of Proteins and Foods, and ed. Springfield, Ill.: Charles C. Thomas.

Chibnall, A. C. (1939). Nitrogen Metabolism in the Plant. Newhaven: Yale University Press.

Chibnall, A. C., Rees, M. W. \& Williams, E. F. (1943). Biochem. F. 37, 354 -

Edwards, L. E., Sealock, R. R., O'Donnell, W. W., Bartlett, G. R., Barclay, M. B., Tully, R., Tybout, R. H., Box, J. \& Murlin, J. R. (1946). F. Nutr. 32, 597.

Graham, W. D., Hsu, P. Y. \& McGinnis, J. (1949). Science, 1ro, 217.

Greene, R. D. \& Black, A. (1944). F. biol. Chem. I55, I.

Greenhut, I. T., Sirny, R. T. \& Elvehjem, C. A. (I948). F. Nutr. 35, 68 g.

Henderson, L. M. \& Snell, E. E. (1948). F. biol. Chem. 172, 15.

Hodson, A. Z. \& Krueger, G. M. (1947). Arch. Biochem. 12, 435.

Horn, M. J. \& Jones, D. B. (1945). F. biol. Chem. I57, I 53.

Horn, M. J., Jones, D. B. \& Blum, A. E. (1946a). Ұ. biol. Chem. 166, 3 I3.

Horn, M. J., Jones, D. B. \& Blum, A. E. (1946b). F. biol. Chem. 166, 321.

Horn, M. J., Jones, D. B. \& Blum, A. E. (1948). F. biol, Chem. I76, 682.

Horn, M. J., Jones, D. B. \& Blum, A. E. (1949). F. biol. Chem. I77, 699.

Kuiken, K. A., Lyman, C. M. \& Hale, F. (1947). F. biol. Chem. I71, 557.

Lindan, O. \& Work, E. (1951). Biochem. F. 48, 342 .

Lubs, H. A. \& Clark, W. M. (I915). F. Wash. Acad. Sci. 5, 609.

Lugg, J. W. H. (1938a). Biochem. $\mathcal{~ . ~ 3 2 , ~} 775$.

Lugg, J. W. H. (1938b). Biochem. F. 32, 2114.

Lugg, J. W. H. (1938c). Biochem. F. 32, 2 I23.

Lyman, C. M. \& Kuiken, K. A. (1948). Fed. Proc. 7, 170.

Lyman, C. M., Moseley, O., Butler, B., Wood, S. \& Hale, F. (1946). Y. biol. Chem. 166, r6r.

Lyman, C. M., Moseley, O., Wood, S., Butler, B. \& Hale, F. (r947). F. biol. Chem. 167, I77.

Macpherson, H. T. (1946). Biochem. F. 40, 470.

Miller, E. J. (1935). Biochem. F. 29, 2344.

Rees, M. W. (1946). Biochem. F. 40, 632.

Schweigert, D. S., McIntire, J. M., Elvehjem, C. A. \& Strong, F. M. (x944). F. biol. Chem. I55, I83.

Smith, E. L. \& Greene, R. D. (1948). 7. biol. Chem. r72, 111.

Stein, W. H. \& Moore, S. (1948). F. biol. Chem. 176, 337.

Stokes, J. L., Gunness, N., Dwyer, I. M. \& Caswell, M. C. (1945). \%. biol. Chem. 160, 35.

Synge, R. L. M. (1945), Advanc. Protein Chem. 2, 10.

Tristram, G. R. (1939). Biochem. $\mathfrak{F} .33,1271$.

Tristram, G. R. (1946). Biochem. F. 40, 721.

Tristram, G. R. (I95I). Advanc. Protein Chem. 5, 84-148.

Wooley, J. G. \& Sebrell, W. H. (1945). Y. biol. Chem. 157, 141. 